\title{
Rate of growth of Pseudomonas fluorescens in donated blood
}

\author{
A P Gibb, K M Martin, G A Davidson, B Walker, W G Murphy
}

\begin{abstract}
Aims-To examine how delayed refrigeration of blood affects the growth of Pseudomonas fluorescens, one of the two most important causes of sepsis resulting from transfusion of contaminated blood. Methods-Two donations of whole blood were each divided into three aliquots and inoculated with $5-10 \mathrm{cfu} / \mathrm{ml}$ of a $P$ fluorescens strain from a case of transfusion associated sepsis. From each donation, one aliquot was placed at $4^{\circ} \mathrm{C}$, one was held at $20^{\circ} \mathrm{C}$ for six hours prior to refrigeration and the third was held at $20^{\circ} \mathrm{C}$ for 24 hours prior to refrigeration. Samples were aseptically withdrawn over 17 days and bacterial counts were determined using a pour plate technique. Results-The rate of growth of $P$ fluorescens in blood at $20^{\circ} \mathrm{C}$ was increased compared with blood at $4^{\circ} \mathrm{C}$. At 24 hours the aliquots held at $20^{\circ} \mathrm{C}$ for six and 24 hours had, respectively, 174 and $29000 \mathrm{cfu} / \mathrm{ml}$ compared with $15 \mathrm{cfu} / \mathrm{ml}$ in aliquots held at $4^{\circ} \mathrm{C}$. There was no evidence of increased killing of $\boldsymbol{P}$ fluorescens at the higher temperature.

Conclusions-These results suggest that blood for transfusion should be refrigerated as soon as possible after collection.

(F Clin Pathol 1995;48:717-718)
\end{abstract}

Medical Microbiology,

University Medical

School,

Teviot Place,

Edinburgh EH8 9AG

A P Gibb

K M Martin

G A Davidson

South-East Scotland

Blood Transfusion

Service,

Royal Infirmary of

Edinburgh,

Edinburgh EH3 9HB

B Walker

W G Murphy

Department of

Medicine,

University of

Edinburgh,

Royal Infirmary of

Edinburgh

W G Murphy

Correspondence to:

Dr A P Gibb,

Department of Microbiology

and Infectious Diseases,

Foothills Hospital,

1403-29 St NW,

Calgary,

Alberta T2N 2T9,

Canada.

Accepted for publication

21 February 1995 Transfusion of blood in which bacteria have multiplied is rare in modern practice, but has a high mortality rate. ${ }^{1-4}$ Two organisms, Yersinia enterocolitica and Pseudomonas fluorescens, which share the ability to multiply at $4^{\circ} \mathrm{C}$, account for most cases. Established methods for prevention of this problem include the use of good aseptic technique, closed collection systems and refrigeration. Standards of practice in many countries require refrigeration of blood within eight hours of collection. ${ }^{56}$

Contamination by $Y$ enterocolitica has increased in frequency over the past decade. ${ }^{12}$ It appears that $Y$ enterocolitica in donated blood derives from an asymptomatic bacteraemia in organism have included delaying refrigeration of blood ${ }^{78}$ in the hope of allowing host defence mechanisms to kill the organisms or allowing the organisms to be engulfed by phagocytes which can subsequently be removed by filtration. ${ }^{9}$ Studies with $Y$ enterocolitica appear to experiments, however, is difficult because of the complex nature of this organism and its response to environmental conditions. ${ }^{10}$

We set out to determine how a delay in refrigeration of donated blood might affect the growth of $P$ fluorescens, which probably derives from the donor's skin. ${ }^{11}$ Simple experiments involving inoculation of small numbers of organisms into freshly donated blood are therefore likely to accurately reflect real contamination events.

\section{Methods}

Pfluorescens strain 079 was isolated from a fatal transfusion reaction involving contaminated platelet depleted blood. ${ }^{12}$ The organism was cultured in nutrient broth at $30^{\circ} \mathrm{C}$ overnight. Aliquots $(0.2 \mathrm{ml})$ of the broth culture were added to $1.8 \mathrm{ml}$ volumes of nutrient broth containing $10 \%$ glycerol and stored at $-20^{\circ} \mathrm{C}$. One vial was thawed, and a viable count performed to calculate the dilution required to inoculate blood samples.

Donations of whole blood were split into aliquots of approximately $100 \mathrm{ml}$ and weighed to give individual volumes. Each aliquot was fitted with a sampling site coupler. A vial of $P$ fluorescens culture was thawed and diluted in saline, and inoculated into each aliquot of blood to achieve a concentration of $5-10 \mathrm{cfu} / \mathrm{ml}$. In the first series of experiments two aliquots from each of six donors were incubated at $4^{\circ} \mathrm{C}$ for 17 days; another two aliquots from each donation were first stored at $20^{\circ} \mathrm{C}$ for 24 hours and then placed at $4^{\circ} \mathrm{C}$ for the next 16 days. In second series of experiments separate aliquots from each of two donors were stored at $4^{\circ} \mathrm{C}$ after initial incubation at $20^{\circ} \mathrm{C}$ for zero, six and 24 hours, respectively.

Samples were withdrawn for bacterial culture the donor. Suggested methods to deal with this support this concept. Interpretation of these actual size of inoculum, and subsequently at intervals up to 17 days. On each occasion a $3 \mathrm{ml}$ sample was collected from each bag and mixed with $150 \mu$ l of $10 \%$ (w/v) saponin (Sigma, Poole, Dorset, UK) to lyse red cells. Triplicate pour plates were prepared by mixing $1 \mathrm{ml}$ samples of lysed blood with $19 \mathrm{ml}$ Isosensitest agar (Oxoid Ltd, Basingstoke, UK). Plates were allowed to set and the number of colonies were counted after 48 hours at $30^{\circ} \mathrm{C}$. Samples collected after 24 hours were serially diluted in sterile saline and $1 \mathrm{ml}$ aliquots of appropriate dilutions cultured as described above.

The susceptibility of $P$ fluorescens strain 079 to complement was tested by incubating bacteria in citrated plasma and in $10 \%$ serum (diluted to $10 \%$ in complement fixation test buffer (Oxoid)). Viable counts after one hour at $37^{\circ} \mathrm{C}$ were compared with saline and buffer controls. Escherichia coli R2 was used as a complement sensitive control strain. 


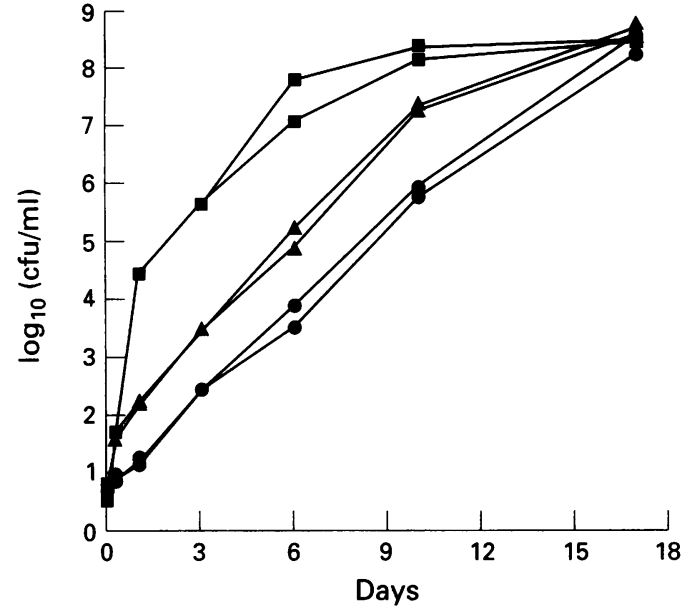

Growth of $P$ fluorescens in experimentally contaminated blood from two donors. Each point represents the mean of triplicate viable counts. $\mathrm{O}$, Aliquots placed at $4^{\circ} \mathrm{C}$ immediately after collection; $\Delta$, aliquots held at $20^{\circ} \mathrm{C}$ for six hours; $\square$, aliquots held at $20^{\circ} \mathrm{C}$ for 24 hours prior to refrigeration.

\section{Results}

In the initial experiment duplicate aliquots from each of six donors were refrigerated at $4^{\circ} \mathrm{C}$ immediately after inoculation and a second set of duplicate aliquots were held at $20^{\circ} \mathrm{C}$ for 24 hours prior to refrigeration. $P$ fluorescens grew in all of the units at a temperature dependent rate. There was no apparent lag phase and no evidence of bacterial killing.

To relate these findings more clearly to current blood transfusion practice, we decided to repeat the experiment and to include a holding time of six hours at $20^{\circ} \mathrm{C}$ prior to refrigeration. Similar results were obtained, with a doubling time of 14.4 hours at $4^{\circ} \mathrm{C}$ compared with two hours at $20^{\circ} \mathrm{C}$ (figure). Holding the blood at $20^{\circ} \mathrm{C}$ for 24 hours resulted in an increase of approximately 100 -fold in the number of bacteria present in the blood between 24 hours and six days. The difference in numbers of bacteria then reduced as growth approached a plateau of approximately $3 \times 10^{8} \mathrm{cfu} / \mathrm{ml}$.

$P$ fluorescens strain 079 was found to be completely resistant to killing by $10 \%$ serum and $100 \%$ plasma, which is compatible with the observation of unimpeded growth of the organism in whole blood.

\section{Discussion}

The results of our investigation suggest that prolonged storage of blood at $20^{\circ} \mathrm{C}$, even for six hours, exacerbates the growth of $P$ fluorescens. As contamination by $P$ fluorescens is likely to occur from an exogenous source, probably the donor's skin, good aseptic technique with an emphasis on skin cleaning remains central to the prevention of contamination by this organism. ${ }^{11}$ There is no extant evidence to suggest that filtration would effectively remove $P$ fluorescens from contaminated blood.

It is reasonable to question whether the differences in growth rate reported here represent real differences in hazard. We have not demonstrated any difference in the ability of $P$ fluorescens to survive at the different temperatures, merely a difference in rate of growth. However, many units are transfused in the first few days after collection at which time the differences in numbers of organisms could be sufficient to increase the mortality rate. Data on the effect of transfusing large numbers of bacteria into humans are not available, and animal data yield variable results which cannot be directly applied to humans. ${ }^{1314}$

It is often assumed that endotoxin is the cause of illness in these circumstances, but it is likely that other bacterial factors also contribute to the outcome. ${ }^{1516}$ Endotoxin assays are a less sensitive measure of bacterial contamination than are bacterial counts in experimentally contaminated blood ${ }^{17}$ and may be influenced by binding of the endotoxin to plasma or red cells. Bacterial endotoxins also vary in their toxicity and the relative potency of $P$ fluorescens endotoxin is not known. We believe, therefore, that endotoxin assay results would not have contributed in a major way to the interpretation of our results.

From the evidence presented here, we are concerned about the suggestion to hold blood at $20^{\circ} \mathrm{C}$ for between six and 24 hours before refrigeration at $4^{\circ} \mathrm{C}$. The incidence of colonisation of skin of normal individuals with $P$ fluorescens is approximately 1 in $400^{11}$ so that the potential for increased morbidity caused by favouring the growth of this organism is high. In view of the lack of clear evidence of benefit from prolonged holding of blood at $20^{\circ} \mathrm{C}$ we conclude that the practice of rapid refrigeration of blood should not be changed.

This work was supported by a grant from Tuta, Lane Cove, New South Wales, Australia.

1 Prentice M. Transfusing Yersinia enterocolitica. BMF 1992; 305:663-4

2 Update: Yersinia enterocolitica bacteremia and endotoxin shock associated with red blood cell transfusions - United States, 1991. MMWR 1991;40:176-8.

3 Wagner SJ, Friedman LI, Dodd RY. Transfusion-associated bacterial sepsis. Clin Microbiol Rev 1994;7:290-302.

4 Sazama K. Bacteria in blood for transfusion. A review. Arch Pathol Lab Med 1994;118:350-65.

5 Department of Health. Guidelines for the blood transfusion services in the United Kingdom 1989. London: HMSO, 1989.

6 Standards for blood banks and transfusion services. 15th edn. Bethesda, Maryland: American Association of Blood Banks, 1993:8.

7 Högman CF, Gong J, Eriksson L, Hambraeus A, Johansson CS. White cells protect donor blood against bacterial contamination. Transfusion 1991;31:620-6.

8 Pietersz RNI, Reesink HW, Pauw W, Dekker WJA, Buisman L. Prevention of Yersinia enterocolitica growth in redblood-cell concentrates. Lancet 1992;340:755-6.

9 Nusbacher J. Yersinia enterocolitica and white cell filtration. Transfusion 1992;32:597-600.

10 Gibb AP, Martin KM, Davidson GA, Walker B, Murphy WG. Modeling the growth of Yersinia enterocolitica in WG. Modeling the growth of Yersinia ente

11 Puckett A, Davison G, Entwistle CC, Barbara JAJ. Post transfusion septicaemia 1980-1989: importance of donor arm cleansing. $\mathcal{f}$ Clin Pathol 1992;45:155-7.

12 Scott J, Boulton FE, Govan JRW, Miles RS, McClelland DBL, Prowse CV. A fatal transfusion reaction associated with blood contaminated with Pseudomonas fluorescens. Vox Sang 1988;54:201-4.

13 Wichterman KA, Baue AE, Chaudry IH. Sepsis and septic shock-a review of laboratory models and a proposal. $f$ Surg Res 1980;29:189-201.

14 Suffrendi AF, Fromm RE, Parker MM, Brenner M, Kovacs JA, Wesley RA, et al. The cardiovascular response of normal humans to the administration of endotoxin. $N$ Engl $\mathcal{H}$ Med 1989;321:280-7.

15 Gibb AP. The role of bacteria in sepsis syndrome. Rev Med Microbiol 1993;4:59-64.

16 Danner RL, Natanson C, Elin RJ, Hosseini JM, Banks S, MacVittie TJ, et al. Pseudomonas aeruginosa compared with Escherichia coli produces less endotoxemia but more cardiovascular dysfunction and mortality in a canine model of septic shock. Chest 1990;98:1480-7.

17 Arduino MJ, Bland LA, Tipple MA, Aguero SM, Favero MS, Jarvis WR. Growth and endotoxin production of Yersinia enterocolitica and Enterobacter agglomerans in packed erythrocytes. $\mathcal{F}$ Clin Microbiol 1989;27:1483-5. 